\title{
System for the evaluation of malting quality of wheat varieties
}

\author{
Vratislav Psota*, Markéta Musilová \\ Research Institute of Brewing and Malting \\ Mostecká 971/7, 61400 Brno \\ Czech Republic
}

${ }^{*}$ Corresponding author: psota@beerresearch.cz

\begin{abstract}
A new system for the calculation of malting quality of wheat varieties was designed. The malting parameters affected by a variety more than by a year or a site were used in the system. These parameters include wort viscosity, soluble nitrogen content, free amino nitrogen content, diastatic power, final attenuation of wort, and extract of malt. The system was used to assess the malting quality in 38 wheat varieties. The point value of each parameter was calculated using the regression equations, and the total value of the malting quality of wheat was determined by the modified "superiority measure" method. The results of the assessment of the wheat malting quality showed considerable differences between the varieties. Several varieties exhibited a more pronounced tendency to accumulate nitrogenous substances in grain. Some varieties, even with a slightly higher content of nitrogenous substances, provided above average malt quality. The set included the varieties that exhibited the optimal content of nitrogenous substances in grain, yet they did not give malt of good quality. Spring wheat varieties Alondra, Anabel, and Seance achieved significantly above average malting quality. Dagmar, Evina, Sultan, Rumor, Sailor, and Brokat exhibited slightly above average malting quality. The proposed system for monitoring malting quality of wheat varieties can help find the varieties suitable for the production of quality wheat malt.
\end{abstract}

Key words: wheat, wheat malt, brewing quality

\section{Introduction}

Wheat grain, similarly as barley grain, is a natural material whose characteristics are affected by a number of external and internal factors. The basic factors determining quality of wheat grain and subsequently malt include the variety and growing conditions. The quality of wheat malt affects not only the individual phases of the beer production but also sensory properties (flavour, colour, foam) of wheat beer. However, the suitability of wheat varieties for the malt and beer production is not systematically monitored.

Quality of wheat malt is assessed according to the same parameters as quality of malt made from barley, although the technology used for the production of wheat malt partly differs from that used for the malt made from barley. The technological process of the wheat beer production is mark- edly influenced by local customs. The differences are in the amount of the extract added with the wheat malt. Usually, for the production of wheat beer, $30 \%$ to $70 \%$ of wheat malt is used. The differences between barley and wheat and technology used for the production of wheat and barley beer require a different view of both input materials.

The effects of the quality of wheat grain on the malt and beer production have not been studied in as much detail as in barley (Back, 2005). The requirements for quality of wheat malt have been discussed in many studies (Sacher and Narziß, 1992; Back, 2005; Tietze et al., 2013; Faltermaier et al., 2013; Faltermaier et al., 2014) and are also given in specifications of malt houses producing wheat malt. 
In the Czech Republic, the system of the evaluation of the malting quality of wheat varieties does not exist. This study represents a possible method for the evaluation spring and winter wheat varieties in terms of their suitability for the production of good wheat malt.

\section{Material and methods}

\subsection{The evaluated parameters}

The parameters for the evaluation of wheat varieties were selected based on the analyses of 11 spring wheat varieties (Sachambula et al., 2017) and 27 winter wheat varieties (Psota et al., 2018). Based on these studies, the following technological parameters of malt and sweet wort were selected for the evaluation: wort viscosity, soluble nitrogen content, free amino nitrogen content, diastatic power, final attenuation, and extract content in the malt dry matter. These parameters characterize cytolytic, proteolytic, and amylolytic modification of wheat malt and were mostly affected by the variety.

\subsection{Determination of weights and limit values}

The weights of the evaluated parameters and their limit values were determined subjectively based on experience and requirements of malt houses and breweries (Table 1).

\subsection{Calculation of the point evaluation for the respective parameters}

A nine-point scale is used: nine points indicate the best level of the parameter, while point one is an unacceptable value.

The conversion of the absolute values of the parameters to the point evaluation is performed using a linear regression equation:

$$
y=a+b \mathrm{x}
$$

where $a$ and $b$ are coefficients (Table 1), $\mathrm{x}$ is the absolute value of the given parameter.

$$
\begin{gathered}
a=1-b \cdot U \mathrm{~L} \\
b=(9-1) /(O \mathrm{~L}-U \mathrm{~L})
\end{gathered}
$$

where $O L$ is the optimal limit and $U L$ the unacceptable limit of the absolute values of the given parameter. An optimum range of 9 points was established for the parameter of nitrogenous substance content. Absolute values lower or higher than the optimum have the point evaluation lower than 9. Two equations are therefore used for the conversion (one for suboptimal values, the other one for superoptimal values).

\subsection{Calculation of the malting quality of wheat}

Calculation of the Malting Quality of Wheat (MQW) is based on the modification of a so-called "superiority measure" (Lin and Binns, 1988). This system is quite flexible and can be easily modified; the studied parameters can be easily changed. The system was used to design the Malting Quality Index for barley (Psota and Kosař, 2002). The MQW for the given variety is calculated from the point values of the individual malting quality parameters:

$$
\begin{gathered}
M Q \mathrm{QW}=9-\sqrt{ } P_{j} \\
\text { where }
\end{gathered}
$$

$M \mathrm{QW}=$ Malting Quality of Wheat,

$$
P_{j}=\sum\left(B_{i j}-9\right)^{2} W_{i} / \sum W_{i}
$$

where, $\mathrm{B}_{\mathrm{ij}}=$ point evaluation of the $i$-parameter of the

$j$-variety and $\mathrm{W} i=$ weight of the $i$-parameter.

The MQW ranges from 1 (worst, unacceptable) to 9 (best, optimal). Since in its principle it is a weighted average of squares of deviations of the point evaluation of the individual parameters from the maximum value ( 9 points), the genotypes reaching similar values in the individual malting quality parameters gain a better evaluation. Thus, a variety that receives 8 points in all characteristics has a higher MQW than, for example, a variety that reached 7 points for two parameters, 9 points for two parameters, and 8 points for the other three parameters.

\section{RESULTS AND DISCUSSION}

\subsection{Selection of the quality parameters}

The parameters significantly influenced by a variety were selected for the malting quality evaluation based on the results of the analyses of wheat varieties published previously (Sachambula et al., 2017; Psota et al., 2018). The selected parameters characterize cytolytic, proteolytic, and amylolytic modification.

\subsection{Content of nitrogenous substances in the non-malted wheat grain}

The amount of the nitrogenous substances in the wheat grain is significantly affected by the environment. In the winter wheat varieties studied for the three-year period, the nitrogenous substance content was affected by the year from $61.7 \%$, locality from $14.4 \%$, and the variety only from $11.3 \%$ (Psota et al., 2018). The effect of the variety on the nitrogenous substance content was substantially lower, nevertheless, it was included in the system for the evaluation of the malting quality of wheat varieties.

The portion of starch in grain declines with the increase of the portion of the nitrogenous substances. 
Table 1 Limit values and weights of qualitative parameters for wheat varieties

\begin{tabular}{|c|c|c|c|c|c|c|c|c|}
\hline & $\begin{array}{l}\frac{n}{c} \\
. \frac{\pi}{2} \\
\frac{\pi}{2} \\
\frac{0}{0}\end{array}$ & 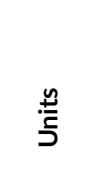 & 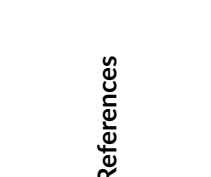 & 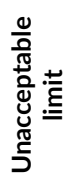 & 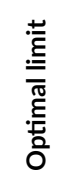 & \multicolumn{2}{|c|}{ 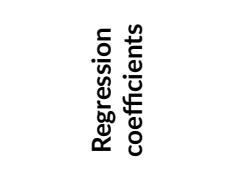 } & \multirow{2}{*}{$\begin{array}{l}\frac{+}{.00} \\
\stackrel{00}{0} \\
\text { W }\end{array}$} \\
\hline & & & & 1 & 9 & a & $b$ & \\
\hline \multirow{2}{*}{$\begin{array}{l}\text { Nitrogen substances in grain } \\
\text { wheat (factor } 6.25 \text { ) }\end{array}$} & \multirow{2}{*}{ PB } & \multirow{2}{*}{$\%$} & \multirow{2}{*}{ EBC 20103.3 .2} & 10.0 & 11.0 & -79.00 & 8.00 & \multirow{2}{*}{0.01} \\
\hline & & & & 12.5 & 11.5 & 101.00 & -8.00 & \\
\hline Extract of malt & E & $\%$ & EBC 20104.5 .1 & 83.0 & 85.0 & -331.00 & 4.00 & 0.30 \\
\hline Diastatic power & DP & u. WK & EBC 20104.12 & 250 & 350 & -19.00 & 0.08 & 0.10 \\
\hline Final attenuation of wort & FA & $\%$ & EBC 20104.11 .1 & 80.0 & 83.0 & -212.33 & 2.67 & 0.10 \\
\hline Free amino nitrogen & FAN & $\mathrm{mg} / \mathrm{l}$ & EBC 20104.10 & 85.0 & 105 & -33.00 & 0.40 & 0.10 \\
\hline Soluble nitrogen in wort & SNw & $\mathrm{mg} / \mathrm{l}$ & EBC 20104.9 .3 & 650 & 750 & -51.00 & 0.08 & 0.10 \\
\hline Viscosity of wort & Vw & mPa.s & EBC 20104.8 & 2.00 & 1.65 & 46.71 & -22.86 & 0.25 \\
\hline \multicolumn{8}{|l|}{ Sum of weights } & 0.96 \\
\hline
\end{tabular}

The increased portion of the nitrogenous substances significantly affects most of the parameters evaluated in malt and wort. For this reason, the nitrogenous substance content was included in the evaluation system. The nitrogenous substance content in the evaluated sample of the given wheat variety must be in the optimal scope or close to this optimum. Malt wheat should contain less than $12 \%$ of nitrogenous substances (Narziß et al., 2017). Nitrogenous substances in wheat grain as well as other cereals are stored mainly in the aleurone layer and in the endosperm.

\subsection{Cytolytic modification}

Viscosity of sweet wort belongs to the basic parameters evaluated in wheat malt as it indicates its usability for the beer production. During malting, cytolytic enzymes degrade cell walls of the endosperm to smaller molecules and initiate the degradation of high molecular weight substances to low molecular weight substances which pass to the sweet wort; this results in lower values of viscosity. As plant fibre has high absorption ability, arabinoxylans, $\beta$-glucans, and dextrins increase wort viscosity (Sadosky et al., 2002). Wheat grain has a lower $\beta$-glucan content than barley grain, but it has more arabinoxylans, increasing thus sweet wort viscosity.

The value of sweet wort viscosity was affected by the variety from $50.0 \%$ in spring wheat varieties and from $81.6 \%$ in winter wheat varieties. The wort viscosity varied from 1.61 to $1.78 \mathrm{mPa}$.s in spring wheat varieties and from 1.69 to $2.31 \mathrm{mPa}$.s in winter wheat varieties (Sachambula et al., 2017; Psota et al., 2018). According to Back (2005), the viscosity value of sweet wort should move below 1.80 mPa.s. Narziß et al. (2017) reported viscosity in a range from 1.65 to $1.85 \mathrm{mPa}$.s. In the sys- tem designed for this study, the values $\leq 1.65 \mathrm{mPa}$.s are considered optimal and the sweet wort viscosity value $\geq$ $2.00 \mathrm{mPa}$.s is unacceptable (Table 1).

\subsection{Proteolytic modification}

During malting, proteolytic modification occurs, i.e. high molecular weight nitrogen compounds are degraded and amino acids, peptides, etc. are formed and become part of sweet wort. Amino acids are important for yeast growth and polypeptides positively affect foam stability and contribute to the fullness of beer (Narziß and Back, 2012). The qualitative composition of nitrogenous substances is characterized by the content of free amino nitrogen (FAN).

Kolbach index informs on the size of the portion of the nitrogenous substances that got into the wort. The value of Kolbach index in the spring wheat varieties was affected from $21.9 \%$ by a year and $34.3 \%$ by the locality; in the winter wheat varieties this value was affected by a year from $52.3 \%$ and from $17.2 \%$ by a locality.

The spring wheat varieties affected the content of soluble nitrogen from $48.7 \%$ and winter wheat varieties from $30.7 \%$. In FAN (mg/l), effects of the spring and winter wheat varieties were at the comparable levels of $26.5 \%$ and $25.1 \%$, respectively (Sachambula et al., 2017; Psota et al., 2018).

The amount of soluble nitrogen depends on the amount of nitrogen in wheat grain and subsequently in malt. During malting, mainly the storage proteins are hydrolysed. Low molecular weight nitrogen compounds, namely amino acids, have a positive effect on fermentation. If the FAN concentration is high enough, yeast has more nutrients and fermentation can proceed faster and alcohol production is higher (Briggs et al., 2004). On the 
other hand, high FAN content can lead to the formation of undesirable flavours (Back, 2005).

Back (2005) reported that the soluble nitrogen content should move in the range of $650-780 \mathrm{mg} / 100 \mathrm{~g}$, i.e. approximately $710-855 \mathrm{mg} / \mathrm{l}$. Jin et al. (2012) found the soluble nitrogen content in a wider range of 849 to $1246 \mathrm{mg} / \mathrm{l}$ and FAN from 120 to $166 \mathrm{mg} / 100 \mathrm{~g}$, i.e. approximately 135 to $185 \mathrm{mg} / \mathrm{l}$. Faltermaier et al. (2013) reported that the content of soluble nitrogen in a typical pale malt ranged from $600-800 \mathrm{mg} / 100 \mathrm{~g}$, which is approximately $660-895 \mathrm{mg} / \mathrm{l}$, and in FAN, from 100 to $140 \mathrm{mg} / 100 \mathrm{~g}$, i.e. approximately 110 to $160 \mathrm{mg} / \mathrm{l}$.

In the spring wheat varieties, the soluble nitrogen content and FAN ranged from 665 to $847 \mathrm{mg} / \mathrm{l}$ and 89 to $116 \mathrm{mg} / \mathrm{l}$, respectively (Sachambula et al., 2017). In the winter wheat varieties, the soluble nitrogen content and FAN ranged from 642 to 832 and 82 to $112 \mathrm{mg} / \mathrm{l}$, respectively (Psota et al., 2018). The share of FAN in the total soluble nitrogen content was around 14\%, which corresponds to the values reported by Narziß et al. (2017). In the proposed evaluation system, the values of soluble nitrogen content of $650 \mathrm{mg} / \mathrm{l}$ and less are considered unacceptable, values of $750 \mathrm{mg} / \mathrm{l}$ and more are considered optimal. In the case of FAN, values of $85 \mathrm{mg} / \mathrm{l}$ or less are considered unacceptable and values of $105 \mathrm{mg} / \mathrm{l}$ or greater are considered optimal (Table 1).

\subsection{Amylolytic modification}

In the evaluation system of malting quality of wheat varieties, amylolytic modification is characterized by the following parameters: diastatic power, final attenuation and, first of all, extract in malt dry matter, a trait with a significant economic impact.

In spring wheat, diastatic power, final attenuation and extract content were affected by the variety from $65.6 \%, 42.8 \%$ and $47.1 \%$, respectively (Sachambula et al., 2017). In winter wheat varieties, the variety was affected by diastatic power from $51.9 \%$ and final attenuation from $47.6 \%$. In this case, the extract was influenced by a variety only from $29.4 \%$, whereas the year influenced this trait from $49.1 \%$ (Psota et al., 2018).

Diastatic power is a parameter characterizing the activity of amylolytic enzymes, namely $\beta$-amylase, that degrade starch to soluble sugars (Dunn, 1974). In spring and winter wheat varieties, diastatic power achieved the average values from 250 to $410 \mathrm{WK}$ un. (Sachambula et al., 2017; Psota et al., 2018), and a similar range has been reported by Narziß and Back (2012). In the evaluation system of malting quality of wheat varieties designed in this study, the values of diastatic power of $250 \mathrm{WK}$ un. are considered to be unacceptably low, and the values of $350 \mathrm{WK}$ un. and higher are taken as optimal (Table 1).

Degradation of starch is also characterized by final attenuation. The average values of this parameter in spring wheat varieties moved from $79.7 \%$ to $81.3 \%$, in winter wheat varieties from $78.6 \%-81.4 \%$ (Sachambula et al., 2017; Psota et al., 2018). A similar range has been reported by Narziß et al. (2017). For the evaluation of malting quality of wheat varieties proposed in this study, the values of final attenuation at the level of $80 \%$ and less are considered unacceptably low and the values at the level of $83 \%$ and higher optimal (Table 1).

Similarly as in barley, the extract content in malt dry matter is affected by the content of nitrogenous substances. The average extract values in spring wheat varieties ranged from $81.9 \%$ to $84.8 \%$, in winter barley varieties it was in the range from $82.3 \%$ to $85.4 \%$ (Sachambula et al., 2017; Psota et al., 2018). This corresponds to the range of $83 \%$ to $85 \%$ reported in the literature (Narziß and Back, 2012; Back, 2005). Based on the results achieved and data from the literature, this study considered the values of the extract content in dry matter of $83 \%$ and less as unacceptably low, and $85 \%$ and more as the optimal (Table 1).

\subsection{Examples of the MQW calculation}

Analytic values of hypothetic varieties and corresponding point evaluation of the individual quality parameters are given in Table 2 .

Table 2 Examples of the MQW calculation

\begin{tabular}{|c|c|c|c|c|c|c|c|c|c|c|c|c|c|c|c|}
\hline Parameters & MQW & $\mathrm{PB}$ & $\mathrm{E}$ & DP & FA & FAN & SNw & $V_{w}$ & PB & $\mathrm{E}$ & $\mathrm{DP}$ & FA & FAN & SNw & Vw \\
\hline Weight & & 0.01 & 0.30 & 0.10 & 0.10 & 0.10 & 0.10 & 0.25 & 0.01 & 0.30 & 0.10 & 0.10 & 0.10 & 0.10 & 0.25 \\
\hline Units & \multirow{2}{*}{$\begin{array}{l}\text { 9-point } \\
\text { scale }\end{array}$} & \multirow{2}{*}{$\%$} & \multirow{2}{*}{$\%$} & \multirow{2}{*}{ WK un. } & \multirow{2}{*}{$\%$} & \multirow{2}{*}{$\mathrm{mg} / \mathrm{l}$} & \multirow{2}{*}{$\mathrm{mg} / \mathrm{l}$} & \multirow{2}{*}{ mPa.s } & \multirow{2}{*}{\multicolumn{7}{|c|}{ 9-point scale }} \\
\hline Varieties & & & & & & & & & & & & & & & \\
\hline A & 3.6 & 11.7 & 83.5 & 307 & 80.1 & 89 & 691 & 1.80 & 7.4 & 3.0 & 5.6 & 1.3 & 2.4 & 4.3 & 5.6 \\
\hline B & 6.3 & 12.0 & 84.5 & 330 & 81.0 & 100 & 700 & 1.70 & 5.0 & 7.0 & 7.4 & 3.7 & 7.0 & 5.0 & 7.9 \\
\hline $\begin{array}{l}\text { Abbreviatio } \\
\text { MQW - Ma } \\
\text { DP - Diasta } \\
\text { Vw - Viscos }\end{array}$ & $\begin{array}{l}\text { qual } \\
\text { ower } \\
\text { of wo }\end{array}$ & $1 \mathrm{~W}$ & $\begin{array}{l}; \text { PB } \\
\text { atten } \\
\text { cale }\end{array}$ & $\begin{array}{l}\text { itroge } \\
\text { ion o } \\
\text { wors }\end{array}$ & $\begin{array}{l}\mathrm{t} ; \mathrm{F} \\
\mathrm{acce}\end{array}$ & & . & $\begin{array}{l}\text { fact } \\
\text { oge } \\
\text { tim }\end{array}$ & $\begin{array}{l}\text { 25) } \\
\text { Iw }\end{array}$ & $2 \wedge$ & $\begin{array}{l}\text { of } \\
\text { og }\end{array}$ & wort & & & \\
\hline
\end{tabular}


Example: MQW calculation, the variety " $\mathrm{A}$ “:

$$
\begin{aligned}
\mathrm{P}_{\mathrm{A}}=(9-7.40)^{2 * 0.01} & =0.03 \\
+(9-3.00)^{2 * 0.30} & =10.80 \\
+(9-5.56)^{2 * 0.10} & =1.18 \\
+(9-1.27)^{2 * 0.10} & =5.98 \\
+(9-2.40)^{2} * 0.10 & =4.36 \\
+(9-4.28)^{2 * 0.10} & =2.23 \\
+(9-5.57)^{2 * 0.25} & =2.94 \\
\text { Total } & =27.51
\end{aligned}
$$

$P_{A}=27.51 / 0.96=28.66$

$$
\mathrm{MQW}_{\mathrm{A}}=9-\sqrt{28.66}=\mathbf{9 - 5 . 3 5}=3.65
$$

\subsection{Malting quality of spring and winter wheat varieties}

Each year, malt samples were made from spring and winter wheat samples obtained from three testing localities in harvest years 2013 to 2015. It means that the results of the analyses were the average of nine measurements. All the varieties thus had the same growing conditions (Sachambula et al., 2017; Psota et al., 2018). The achieved results were used for the calculation of malting quality using the proposed system.

Some spring wheat varieties did not provide samples with the optimum content of the nitrogenous substances $(11.0 \%$ to $11.5 \%)$; this had a negative impact on the extract content and some other characteristics. Probably some wheat varieties are more susceptible to higher nitrogen accumulation in the grain (Table 3). Spring wheat varieties Alondra, Anabel, and Seance achieved significantly above-average malting quality.
Example: MQW calculation, the variety "B":

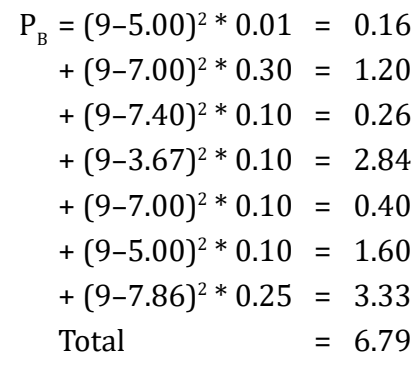

$P_{B}=6.79 / 0.96=7.07$

$\mathrm{MQW}_{\mathrm{B}}=9-\sqrt{7.07}=9-2.66=6.34$

Some winter wheat varieties also had a strong tendency to accumulate nitrogenous substances in the grain. Some varieties, even with a slightly increased content of the nitrogenous substances in the grain, provided above-average quality malt. The set includes the varieties with the optimal nitrogenous substance content in the grain, yet they

\begin{tabular}{|c|c|c|c|c|c|c|c|c|c|c|c|c|c|c|c|}
\hline Parameters & \multirow{2}{*}{ MQW } & PB & E & DP & FA & FAN & $\mathrm{SNw}$ & $V_{w}$ & PB & E & DP & FA & FAN & SNw & $V_{w}$ \\
\hline Weight & & 0.01 & 0.30 & 0.10 & 0.10 & 0.10 & 0.10 & 0.25 & 0.01 & 0.30 & 0.10 & 0.10 & 0.10 & 0.10 & 0.25 \\
\hline Units & \multirow{2}{*}{$\begin{array}{l}\text { 9-point } \\
\text { scale }\end{array}$} & \multirow{2}{*}{$\%$} & \multirow{2}{*}{$\%$} & \multirow{2}{*}{ WK un. } & \multirow{2}{*}{$\%$} & \multirow{2}{*}{$\mathrm{mg} / \mathrm{l}$} & \multirow{2}{*}{$\mathrm{mg} / \mathrm{l}$} & \multirow{2}{*}{ mPa.s } & \multirow{2}{*}{\multicolumn{7}{|c|}{ 9-point scale }} \\
\hline Varieties & & & & & & & & & & & & & & & \\
\hline Alondra & 6.5 & 11.3 & 84.8 & 334 & 80.6 & 103 & 699 & 1.65 & 9.0 & 8.3 & 7.7 & 2.7 & 8.2 & 4.9 & 9.0 \\
\hline Anabel & 6.1 & 11.7 & 84.1 & 327 & 81.3 & 107 & 728 & 1.76 & 7.4 & 5.4 & 7.2 & 4.4 & 9.0 & 7.2 & 6.4 \\
\hline Seance & 5.9 & 11.4 & 84.7 & 312 & 80.8 & 101 & 672 & 1.64 & 9.0 & 7.7 & 6.0 & 3.1 & 7.4 & 2.8 & 9.0 \\
\hline Tercie & 5.3 & 11.7 & 83.9 & 305 & 80.9 & 100 & 724 & 1.78 & 7.2 & 4.6 & 5.4 & 3.3 & 7.0 & 6.9 & 6.0 \\
\hline Izzy & 4.6 & 11.9 & 83.2 & 413 & 81.3 & 107 & 758 & 1.67 & 5.9 & 1.7 & 9.0 & 4.4 & 9.0 & 9.0 & 8.6 \\
\hline Dafne & 4.5 & 11.7 & 83.8 & 353 & 80.9 & 89 & 665 & 1.73 & 7.7 & 4.2 & 9.0 & 3.3 & 2.6 & 2.2 & 7.1 \\
\hline Astrid & 4.3 & 12.1 & 83.2 & 311 & 81.0 & 100 & 717 & 1.61 & 4.0 & 1.7 & 5.9 & 3.8 & 7.0 & 6.4 & 9.0 \\
\hline KWS Akvilon & 4.0 & 12.2 & 83.4 & 285 & 79.7 & 94 & 722 & 1.70 & 3.8 & 2.8 & 3.8 & 1.0 & 4.6 & 6.8 & 7.8 \\
\hline KWS Scirocco & 4.0 & 12.8 & 82.9 & 364 & 80.6 & 116 & 847 & 1.63 & 1.0 & 1.0 & 9.0 & 2.7 & 9.0 & 9.0 & 9.0 \\
\hline KWS Chamsin & 3.8 & 12.2 & 81.9 & 277 & 81.3 & 102 & 727 & 1.71 & 3.5 & 1.0 & 3.2 & 4.5 & 7.8 & 7.2 & 7.7 \\
\hline Quintus & 3.4 & 12.2 & 82.3 & 229 & 80.7 & 110 & 768 & 1.65 & 3.8 & 1.0 & 1.0 & 2.7 & 9.0 & 9.0 & 9.0 \\
\hline \multicolumn{16}{|l|}{ Abbreviations: } \\
\hline
\end{tabular}
did not provide good quality malt. The varieties Dagmar, Evina, Sultan, Rumor, Sailor, and Brokat showed a slightly above-average malting quality (Table 4).

Wheat varieties are bred primarily for bakery or feed use. In both cases, the increased nitrogenous substance accumulation, clearly exhibited by some varieties, is a positive trait. Breeding for malting quality is performed only to a limited extent.

Table 3 Spring wheat malting quality 
Table 4 Winter wheat malting quality

\begin{tabular}{|c|c|c|c|c|c|c|c|c|c|c|c|c|c|c|c|}
\hline Parameters & \multirow{2}{*}{ MQW } & PB & E & DP & FA & FAN & $\mathrm{SNw}$ & $V_{w}$ & PB & $E$ & DP & FA & FAN & SNw & Vw \\
\hline Weight & & 0.01 & 0.30 & 0.10 & 0.10 & 0.10 & 0.10 & 0.25 & 0.01 & 0.30 & 0.10 & 0.10 & 0.10 & 0.10 & 0.25 \\
\hline Units & \multirow{2}{*}{$\begin{array}{l}\text { 9-point } \\
\text { scale }\end{array}$} & \multirow{2}{*}{$\%$} & \multirow{2}{*}{$\%$} & \multirow{2}{*}{ WK un. } & \multirow{2}{*}{$\%$} & \multirow{2}{*}{$\mathrm{mg} / \mathrm{I}$} & \multirow{2}{*}{$\mathrm{mg} / \mathrm{l}$} & \multirow{2}{*}{ mPa.s } & \multirow{2}{*}{\multicolumn{7}{|c|}{ 9-point scale }} \\
\hline Varieties & & & & & & & & & & & & & & & \\
\hline Dagmar & 5.2 & 11.8 & 84.8 & 251 & 79.7 & 109 & 754 & 1.74 & 6.3 & 8.1 & 1.1 & 1.0 & 9.0 & 9.0 & 6.9 \\
\hline Evina & 5.2 & 12.1 & 83.8 & 312 & 80.6 & 112 & 708 & 1.69 & 4.4 & 4.0 & 5.9 & 2.5 & 9.0 & 5.6 & 8.1 \\
\hline Sultan & 5.1 & 12.1 & 84.1 & 332 & 79.3 & 109 & 688 & 1.75 & 4.6 & 5.4 & 7.6 & 1.0 & 9.0 & 4.1 & 6.7 \\
\hline Rumor & 5.0 & 10.9 & 84.9 & 319 & 80.0 & 97 & 616 & 1.73 & 7.8 & 8.6 & 6.5 & 1.0 & 5.9 & 1.0 & 7.3 \\
\hline Sailor & 4.8 & 11.5 & 84.5 & 266 & 79.7 & 108 & 668 & 1.73 & 8.9 & 7.1 & 2.3 & 1.0 & 9.0 & 2.4 & 7.1 \\
\hline Brokat & 4.5 & 11.3 & 84.2 & 312 & 79.7 & 102 & 602 & 1.77 & 9.0 & 5.7 & 5.9 & 1.0 & 7.7 & 1.0 & 6.3 \\
\hline Seladon & 4.5 & 10.8 & 84.8 & 294 & 79.7 & 95 & 604 & 1.80 & 7.2 & 8.3 & 4.5 & 1.0 & 4.8 & 1.0 & 5.5 \\
\hline Artist & 4.2 & 10.8 & 84.0 & 324 & 80.2 & 91 & 598 & 1.78 & 7.2 & 5.2 & 6.9 & 1.4 & 3.5 & 1.0 & 6.0 \\
\hline Lavantus & 4.0 & 11.1 & 84.1 & 288 & 79.6 & 93 & 588 & 1.78 & 9.0 & 5.3 & 4.0 & 1.0 & 4.1 & 1.0 & 6.1 \\
\hline Elan & 4.0 & 11.7 & 83.8 & 348 & 79.6 & 102 & 662 & 1.86 & 7.7 & 4.4 & 8.8 & 1.0 & 7.7 & 2.0 & 4.1 \\
\hline Etana & 3.8 & 11.3 & 83.4 & 303 & 80.3 & 100 & 657 & 1.72 & 9.0 & 2.5 & 5.3 & 1.8 & 7.0 & 1.6 & 7.4 \\
\hline Vanessa & 3.8 & 10.7 & 84.0 & 401 & 79.4 & 92 & 662 & 1.88 & 6.3 & 5.0 & 9.0 & 1.0 & 3.7 & 1.9 & 3.6 \\
\hline Bohemia & 3.3 & 12.4 & 81.9 & 299 & 81.0 & 105 & 654 & 1.75 & 2.1 & 1.0 & 4.9 & 3.8 & 9.0 & 1.3 & 6.7 \\
\hline Annie & 3.2 & 12.7 & 82.4 & 317 & 80.8 & 104 & 684 & 1.85 & 1.0 & 1.0 & 6.4 & 3.2 & 8.6 & 3.7 & 4.5 \\
\hline Fabius & 3.2 & 11.6 & 83.4 & 305 & 80.9 & 93 & 629 & 1.88 & 7.9 & 2.7 & 5.4 & 3.3 & 4.1 & 1.0 & 3.8 \\
\hline Cimrmanova raná & 3.1 & 13.0 & 82.2 & 248 & 81.4 & 100 & 667 & 1.71 & 1.0 & 1.0 & 1.0 & 4.7 & 7.2 & 2.4 & 7.5 \\
\hline Elly & 2.9 & 11.7 & 82.5 & 319 & 80.0 & 95 & 588 & 1.76 & 7.3 & 1.0 & 6.5 & 1.0 & 4.9 & 1.0 & 6.4 \\
\hline Tobak & 2.8 & 11.1 & 83.6 & 250 & 79.3 & 96 & 622 & 1.88 & 9.0 & 3.5 & 1.0 & 1.0 & 5.6 & 1.0 & 3.7 \\
\hline Turandot & 2.8 & 11.3 & 83.7 & 307 & 80.3 & 86 & 599 & 1.93 & 9.0 & 4.0 & 5.6 & 1.7 & 1.3 & 1.0 & 2.5 \\
\hline Patras & 2.7 & 11.6 & 84.1 & 307 & 78.6 & 88 & 640 & 2.03 & 8.5 & 5.5 & 5.6 & 1.0 & 2.2 & 1.0 & 1.0 \\
\hline Athlon & 2.7 & 12.8 & 82.6 & 281 & 78.9 & 106 & 688 & 1.87 & 1.0 & 1.0 & 3.4 & 1.0 & 9.0 & 4.0 & 3.9 \\
\hline KWS Ozon & 2.5 & 11.1 & 83.6 & 295 & 79.6 & 82 & 593 & 1.94 & 9.0 & 3.4 & 4.6 & 1.0 & 1.0 & 1.0 & 2.5 \\
\hline Matylda & 2.3 & 11.6 & 82.6 & 290 & 79.9 & 88 & 582 & 1.82 & 8.3 & 1.0 & 4.2 & 1.0 & 2.3 & 1.0 & 5.2 \\
\hline Genius & 1.9 & 12.3 & 81.9 & 295 & 79.1 & 107 & 670 & 2.10 & 3.0 & 1.0 & 4.6 & 1.0 & 9.0 & 2.6 & 1.0 \\
\hline Matchball & 1.5 & 11.1 & 82.7 & 347 & 78.9 & 82 & 640 & 2.31 & 9.0 & 1.0 & 8.8 & 1.0 & 1.0 & 1.0 & 1.0 \\
\hline Fakir & 1.3 & 12.0 & 82.3 & 285 & 79.1 & 86 & 585 & 2.12 & 5.3 & 1.0 & 3.8 & 1.0 & 1.4 & 1.0 & 1.0 \\
\hline Zeppelin & 1.3 & 11.7 & 82.6 & 284 & 79.2 & 86 & 583 & 2.13 & 7.3 & 1.0 & 3.7 & 1.0 & 1.2 & 1.0 & 1.0 \\
\hline \multicolumn{16}{|l|}{ Abbreviations: } \\
\hline
\end{tabular}

\section{Conclusion}

Wheat varieties are bred primarily for purposes of the milling-baking industry. If the variety does not meet the baking quality and provides a high yield, it is classified as a feed variety without any indication of the feed quality. The wheat grain is also used for malt production. However, malting quality is not routinely monitored in wheat. From the parameters commonly determined in malt produced from barley, we selected the parameters that characterize cytolytic (viscosity of wort), proteolytic (contents of soluble nitrogen and FAN) and amylolytic modification (diastatic power, final attenuation, and extract content in malt dry matter) and which were more markedly affected by a variety. These parameters were used for designing a system for the evaluation of the malting quality of wheat varieties. The system detected the wheat varieties with slightly to markedly above-average malting quality. To find wheat varieties providing malt suitable for the production of wheat beer, it will be necessary to monitor the malting quality systematically. 


\section{Acknowledgements}

This study was performed within the project TE02000177 of the Technological Agency of the Czech Republic.

\section{References}

Back, W., 2005: Ausgewählte Kapitel der Brauereitechnologie. Fachverlag Hans Carl, Nürnberg. ISBN 3-418-00802-X.

Briggs, D. E., Boulton, C. A., Brookes, P. A., Stevens, R., 2004: Brewing. Science and Practice, CRC Press, Boca Raton, FL. ISBN-13: 9781855734906.

Dunn, G., (1974). A model for starch breaks down in higher plants. Phytochemistry, 13(8), 1341-1346. https://doi.org/10.1016/00319422(74)80289-X

EBC Analysis committee, 2010: Analytica-EBC. Barley: 3.2 Moisture content of barley, 3.3.2 Total nitrogen of barley, Malt: 4.2 Moisture content of malt, 4.5.1 Extract of malt: Congress mash, 4.8 Viscosity of laboratory wort from malt, 4.9.3 Soluble nitrogen of malt, 4.10 Free amino nitrogen of malt by spectrophotometry, 4.11 Fermentability, final attenuation of laboratory wort from malt, 4.12 Diastatic power of malt. Nüremberg: Fachverlag Hans Carl. ISBN 978-3-418-00759-5.

Faltermaier, A., Waters, D., Becker, T., Arendt, E., Gastl, M., (2013). Protein modifications and metabolic changes taking place during the malting of common wheat (Triticum aestivum L.). J. Am. Soc. Brew. Chem., 71(3), 153-160. https://doi.org/10.1094/ASBCJ-2013-0613-01

Faltermaier, A., Waters, D., Becker, T., Arendt, E., Gastl, M., (2014). Common wheat (Triticum aestivum L.) and its use as a brewing cereal - a review. J. Inst. Brew. 120(1), 1-15. https://doi.org/10.1002/jib.107

Jin, Y., Du, J., Zhang, K., Xie, L., Li, P., (2012). Relationship between Kolbach index and other quality parameters of wheat malt. J. Inst. Brew. 118(1), 57-62. https://doi.org/10.1002/jib.15
Lin, C. S., Binns, M. R., (1988). A superiority measure of cultivar performance for cultivar x location data. Can. J. Plant Sci., 68(1), 193-198. https://doi.org/10.4141/cjps88-018

Narziß, L., Back, W., 2012: Die Bierbrauerei: Band 2, Technologie der Würzebereitung, 8 ed., Wiley-VHC, Weinheim. ISBN: 978-3-527-32532-0.

Narziß, L., Back, W., Gastl, M., Zarnkow, M., 2017: Abriss der Bierbrauerei. Wiley-VCH, Weinheim. ISBN: 978-3-527-34036-1.

Psota, V., Kosař, K., (2002). Malting quality index. Kvasny Prumysl, 2002; 48(6): 142-148. https://doi.org/10.18832/kp2002011

Psota, V., Musilová, M., Sachambula, L., Horáková, V., Přinosil, A., Šmíd, F., Adámková, K., Adam, M., (2018). Malting quality of winter wheat (Triticum aestivum L.). Kvasny Prumysl, 64 (6), 302-313. https://doi. org/10.18832/kp201832

Sachambula, L., Psota, V., Musilová, M., Horáková, V., Přinosil, A., Šmíd, F., Adámková, K., Adam, M., (2017). Malting quality of spring wheat varieties. Kvasny Prumysl, 63(6), 314-322. https://doi.org/10.18832/ kp201731

Sacher, B., Narziß, L., (1992). Rechnerische Auswertungen von Kleinmälzeungsversuchen mit Winterweizen unter besonderer Berücksichtingung der Ernte 1991. Monatsschrift für Brauwissenschaft, 45(12), 404-412.

Sadosky, P., Schwarz, P. B., Horsley, R. D., (2002). Effect of arabinoxylans, beta-glucans, and dextrins on the viscosity and membrane filterability of a beer model solution. J. Am. Soc. Brew. Chem., 60(4), 153-162. https://doi.org/10.1094/ASBCJ-60-0153

Titze, J., Faltermaier, A., Schnitzenbaumer, B., Gastl, M., Becker, T., Ilberg, V., Arendt, E. K., (2013). Theoretical study on a statistical method for the simple and reliable pre-selection of wheat malt types for brewing purposes based on generally accepted quality characteristics, J. Am. Soc. Brew. Chem., 71(2), 67-75. https://doi.org/10.1094/ASBCJ-2013-0407-01 